\title{
REKONSTRUKSI KOTA KOLONIAL SALATIGA \\ DAN KONTRIBUSI TEKNOLOGI GEOGRAPHICAL INFORMATION SYSTEM
}

\author{
Muh Khoirul Anwar \\ Pendidikan Sejarah Fakultas Keguruan dan Ilmu Pendidikan \\ Universitas Kristen Satya Wacana, Salatiga, Indonesia \\ E-mail: 152014021@gmail.uksw.edu
}

\section{ABSTRACT}

Salatiga City was lokated on the hillside of Merbabu Mountain and on highland has a fresh air and cool climate. Salatiga City also located on strategist area, reachable from Semarang, Solo, Ambarawa, and Magelang. Salatiga is very interesting for European that lives in there at the Colonial Era. The implication for Modern Salatiga is to many historical buildings with classical European style in Salatiga. There is a well-preserved building, but also same building was not preserved and destroyed. Historical building is a cultural heritage and national treasure that can be used for many good things, such as science or economics. To raise the awareness of the folk about historical buildings, we need to make publication and educate the folk about how important the historical building was. To get the publication material and education material, was held historical research with technical approach in a form of using Geographical Information System as research tools. As expected from this research can raise the awareness of the folks about how important the historical building.

Keyword: Colonial Building, History of Salatiga Town, and Geography Information System

\section{JEJAK AWAL KOTA SALATIGA: PENGANTAR}

Terbentuknya Kota Salatiga memiliki sejarah panjang. Kota ini terletak di Jawa Tengah, dan dalam riwayat awalnya terdapat pada prasasti Plumpungan berangka tahun 750 M. Dalam Prasasti tercatat sebuah watak (wilayah setingkat desa pada era Kerajaan Medang) bernama watak I hamra yang berada di wanua (gabungan dari beberapa watak yang dipimpin oleh seorang rakai) bernama wanua I trigosthya. Wilayah wanua I trigosthya ini diyakini sebagai cikal bakal kota Salatiga saat ini, sehingga diyakini bahwa Salatiga sudah dihuni sejak 750 M (Boechari, 2002: 67). Pada perkembangannya, yakni tahun 1757, Salatiga menjadi tempat berlangsungnya perjanjian antara R.M. Said dengan Sunan Pakubuwono III dari Kasunanan Surakarta 
dengan VOC (Vereenigde Oost-Indische Compagnie). Perjanjian itu dikenal dengan Perjanjian Salatiga (Harini, 2010: 52).

Perkembangan Kota Salatiga masa kolonial tidak terlepas dari perkembangan sistem pemerintahan. Tuntutan orang-orang Belanda yang semakin banyak bermukim di Salatiga adalah untuk memperoleh fasilitas yang lebih baik dan mendapat kewenangan yang lebih luas mengelola daerah jajahannya. Dalam kaitan itu, Salatiga menjadi salah satu daerah gemeente, sebagaimana yang dituangkan dalam Staatsblad tahun 1917 No. 266, tanggal 25 Juni 1917. Keputusan gubernur jenderal itu secara admistratif mengukuhkan Salatiga sebagai daerah yang berkembang bersama-sama dengan Sidorejo Lor, Kutowinangun, Kalicacing, Ledok, Gendongan, dan Mangunsari (Wuryani, 2006: 56-59).

Dalam perkembangan sejarahnya dari masa wanua I trigosthya sampai masa kolonial Belanda, masyarakat Salatiga banyak meninggalkan peninggalan sejarah baik berupa artefak, kesenian, maupun bangunan. Terkait dengan bangunan, peninggalan terbanyak berasal dari masa Kolonial Belanda. Dalam penelitian yang dilakukan oleh Bappeda Kota Salatiga dan Balai Pelestarian Cagar Budaya (BPCB) Jawa Tengah tahun 2009, tercatat ada 144 bangunan berciri khas kolonial yang masih tersisa (Bappeda Kota Salaiga, 2009: 342), namun apakah jumlah bangunannya masih 144 atau berkurang? Ada kemungkinan bangunan cagar budaya dengan arsitektur kolonial di kota Salatiga tidak seperti yang telah tercatat oleh Tim Peneliti Bappeda. Hal ini didasarkan pada kemutakhiran metode dan tehnik pengumpulan data yang dilakukan oleh tim peneliti Pekan Kreativitas Mahasiswa (PKM), Program Studi Pendidikan Sejarah Universitas Kristen Satya Wacana 2018.

Fakta-fakta tersebut di atas mendorong penelitian lebih lanjut, terutama dalam memetakan kembali bangunan berciri kolonial di Kota Salatiga dan kemudian melakukan merekonstruksi ulang tata kota Kolonial Salatiga yang berbasis pada data peninggalan yang masih ada (mutakhir). Dengan demikian, penelitian ini menghadirkan deskripsi bagaimana tata Kota Kolonial Salatiga pada masa Hindia Belanda dan mengapa Sistem Informasi Geografis (GIS) memberi kontribusi pada sejarah pemetaan dan perkembangan Kota Salatiga?". Penelitian ini bertujuan untuk menjelaskan desain dan tata kota Kolonial Salatiga yang berbasis pada penggunaan data GIS.

\section{SEJARAH DAN SISTEM INFORMASI GEOGRAFIS (GIS)}

Untuk memecahkan permasalahan spasial mengenai sejarah kota Salatiga, maka proses rekonstruksi kawasan Kota Kolonial Salatiga dilaksanakan menggunakan pendekatan spasial, yaitu pendekatan penelitian dengan kajian dalam lingkup kewilayahan atau berbasis peta wilayah. Pendekatan ini biasanya dilakukan 
oleh disiplin geografi. Antara geografi dan sejarah, aspek spasial menjadi titik persinggungannya, sehingga kontribusi geografi pada disiplin sejarah, salah satunya pada aspek spasial tersebut. Pada era teknologi dan kemajuan ilmu pengetahuan, sejarah mendapat bantuan luar biasa dari sisi pemetaan, salah satunya adalah pada ruang kota. Bantuan teknologi pada sejarah, sebagian di antaranya adalah melalui penggunaan teknologi GIS. GIS memudahkan pemahaman atas ruang kajian sejarah, khususnya sejarah kota atau sejarah yang spasialnya pada level mikro, seperti pada sejarah desa, kabupaten, atau propinsi. Perubahan morfologi suatu kawasan bisa disimulasikan dengan bantuan teknologi GIS, termasuk dalam rekonstruksi Kota Salatiga. Pendekatan ini membantu juga dalam mengenai hubungan antara benda/bangunan cagar budaya dengan konteks wilayah di sekitarnya. Alat bantu Geographical Information System (GIS) berfungsi untuk mengumpulkan, menyimpan, modelling, analisa dan menampilkan data keruangan berdasarkan referensi lokasi atau koordinat yang didapatkan di lapangan (Prayoga, 2016: 14)

\section{MENGENALKAN GEOGRAPHICAL INFORMATION SYSTEM (GIS)}

Sistem Informasi Geografis atau disingat dalam bahasa Ingris (GIS) tidak begitu populer dalam kajian sejarah. GIS populer pada disiplin seperti Arkeologi, studi geografis kewilayahan, meteorologi, militer, dan sebagainya. Ketidak-populeran ini sebagian disebabkan oleh terpetaknya rumpun ilmu, seolah-olah sejarah tidak bersinggungan dengan teknologi. Peristiwa sejarah seperti perang, perebutan wilayah, diaspora, migrasi, perluasan wilayah kota, pendirian bangunan, sebenarnya sangat dekat dengan teknologi. Persoalannya terletak pada bagaimana menarasikan persinggungan itu dalam konteks historis. Agar persentuhan ini lebih dekat, di bawah ini disajikan penjelasan singakt tentang Sistem Informasi Geografis (GIS).

Geographical Information System adalah suatu sistem untuk mengumpulkan, menyimpan, memanipulasi, menganalisis, dan menyajikan berbagai data dalam dimensi keruangan yang memiliki referensi geografis atau acuan lokasi. GIS secara khusus merupakan suatu sistem informasi berbasiskan geografi menggunakan perangkat komputer (Yuwono, 2007: 2).

\section{- Komponen GIS}

Dalam pengoperasian GIS diperlukan tiga komponen dasar, yaitu hardware, software, dan brainware. Hardware adalah komponen-komponen fisik yang digunakan untuk keseluruhan pengerjaan GIS terutama komponen Input dan Output, seperti: komputer, scanner, GPS (Global Positioning System) receiver, kamera, printer. Software adalah program yang digunakan untuk mengontrol kerja perangkat keras dan untuk melaksanakan pengolahan data-data spasial, contoh-contoh software yang digunakan dalam pengolahan GIS antara lain: 
ArcGis, Quantum GIS, Global Mapper, AutoCad Map, GRASS GIS. Untuk software yang digunakan dalam penelitian ini adalah Quantum GIS. Brainware adalah perangkat pikir manusia yang digunakan untuk mengontrol aspek tujuan, manfaat, alasan, dan justifikasi penggunaan GIS (Yuwono, 2007: 2-3). Untuk memudahkan akses dan penggunaan data GIS bisa menggunakan teknologi dan software converter, agar mudah digunakan oleh pemula, termasuk sejarawan.

- Empat Kegiatan Pokok Dalam GIS

Dalam menggunakan GIS terdapat empat kegiatan pokok, yaitu; Pertama adalah input. Digitasi (mengubah data spasial hasil survei menjadi data digital), Scanning, transformasi data, konversi data, dan koneksi data. Kedua, Manajemen. Pengelolaan basis data (kumpulan data grafis dan table attribute yang saling berkaitan menjadi satu kesatuan), struktur data, kamus data, meta data, standarisasi data, dan kontrol data. Ketiga, Analisis/Proses. Overlay, spatialjoin, buffer, digitalelevation model, network analysis, kalkulasi data, integrasi data. Keempat, Presentasi/Output. Mengatur komposisi peta, mengatur tampilan peta, mencetak peta (Yuwono, 2007: 3).

Dalam tahap analisis penulis menggunakan dua jenis analisis yaitu analisis spasial dan analisis kontekstual. Analisis spasial digunakan untuk menganalisis distribusi bangunan kolonial, mencari kerapatan masing-masing sektor kemudian menemukan pola distribusi bangunan (Prayoga, 2016: 17). Analisis kontekstual adalah analisis pada suatu sumber, dalam hal ini bangunan kolonial untuk kemudian dicari hubungannya dengan perilaku masyarakat sebagai suatu sistem perilaku budaya. Analisis ini digunakan untuk melihat hubungan antara masing-masing bangunan kolonial di Salatiga sehingga terlihat adanya keterkaitan dari masing-masing bangunan (Martasari, 2016: 20). Setelah ditemukan keterkaitan antar bangunan, maka dilakukan analisis fungsi wilayah terhadap lokasi bangunan yang saling berkaitan tersebut. Dari hasil analisis tersebut ditarik sebuah acuan mengenai zonasi wilayah berdasarkan fungsi sebuah wilayah, misalnya: kawasan militer; kawasan hunian; kawasan perdagangan; dan lain sebagainya kemudian dari hasil analisis dibuat sebuah peta tematik dengan beberapa zonasi-zonasi wilayah berdasarkan fungsinya di masa kolonial. Peta tematik tersebut yang akan dijadikan acuan rekonstruksi kota Kolonial Salatiga 


\section{SEJARAH DAN REKONSTRUKSI KOTA KOLONIAL SALATIGA}

Bukti-bukti arkeologis yang ditemukan di Salatiga dan sekitarnya menunjukkan bahwa pada abad VII di Salatiga sudah terdapat aktivitas sosial dan ekonomi dengan memanfaatkan Sungai Tuntang dan jalur darat tradisional sebagai jalur niaga kuno menuju pantai Utara Jawa, seperti Jepara dan Rembang sebagai pelabuhan dagang di Pulau Jawa. Bukti-bukti arkeologis ini berupa fondasi dan reruntuhan candi, arca ganeca, arca dwarapala, lingga, yoni, nandi dan prasasti Hampra atau Plumpungan. Bukti-bukti arkeologis ini didukung pula dengan temuantemuan lain berupa cerita rakyat mengenai toponimi suatu tempat, seperti Cungkup, Kemiri Candi, dsb. Dari bukti-bikti arkeologis dan tradisi lisan ini, pemerintah Salatiga kemudian menggunakan batu prasasti Plumpungan untuk dijadikan sebagai dasar terbentuknya hari jadi kota Salatiga 24 Juli 750 M. Prasasti Plumpungan ini merupakan satu-satunya sumber tertua yang ditemukan di dusun Plumpungan, Desa Kauman Kidul, Kecamatan Sidorejo, kota Salatiga. Menurut tradisi lisan, Salatiga dihubungkan dengan cerita perjalanan Ki Ageng Pandanarang yang sering disebut pula dengan Ki Ageng Pandanaran dalam kegiatan keagamaannya dari Semarang menuju Bayat (Klaten) pada akhir abad XVI. Tradisi lisan mengenai asalusul nama Salatiga ini terdapat berbagai versi yang selalu berkaitan dengan nama Salatiga maupun perjalanan keagamaan Ki Ageng Pandanarang ke pedalaman Jawa Tengah

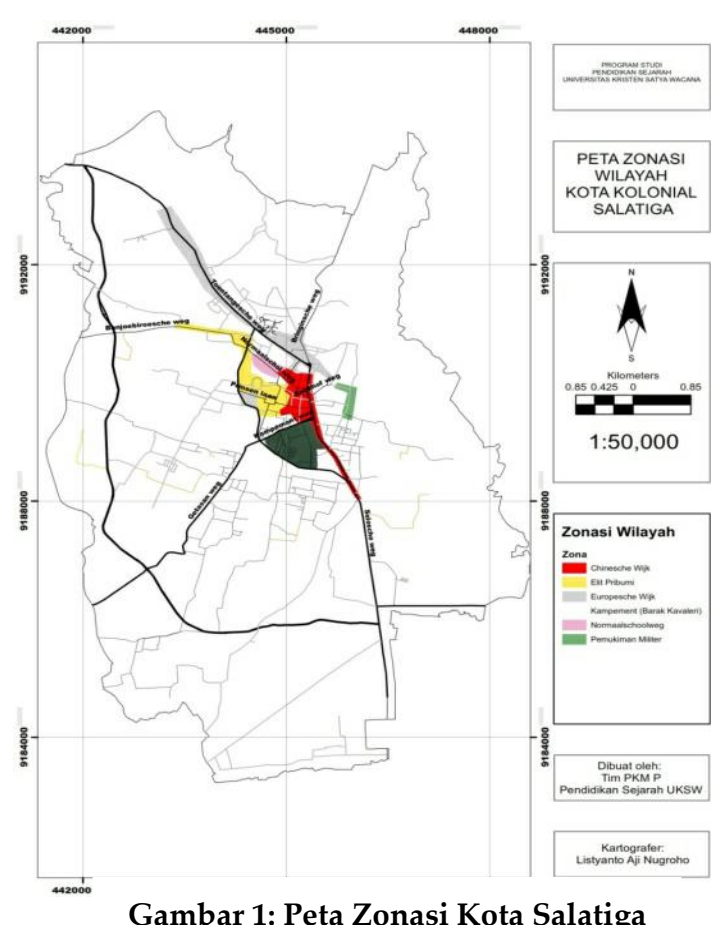

Gambar 1: Peta Zonasi Kota Salatiga (Wuryani, 2006: 21 - 22).

Kota Salatiga yang berada pada ketinggian antar 450 - $800 \mathrm{~m}$ dpl secara marfologis berada di daerah cekungan kaki Gunung Merbabu dan diantara gununggunung kecil antara lain Gajah Mungkur, Telomoyo, Payung dan Rong. Dari kondisi geografisnya yang dikelilingi oleh gunung-gunung kota Salatiga pada sisi barat terdapat danau alam berupa Danau Rawa Pening menjadikan bentang alam di kota Salatiga lengkap antara pegunungan, dataran rendah, dan wilayah perairan. Hal ini yang semakin membuat bangsa Eropa betah dan tertarik dengan kota Salatiga. 
Tatanan kota Kolonial Salatiga memiliki pola radial ${ }^{1}$, berpusat di tengah kota dan terdapat empat percabangan jalan besar menuju ke wilayah luar kota. Dengan pola kota yang berbentuk radial, pusat kota dapat dijangkau dari berbagai wilayah.

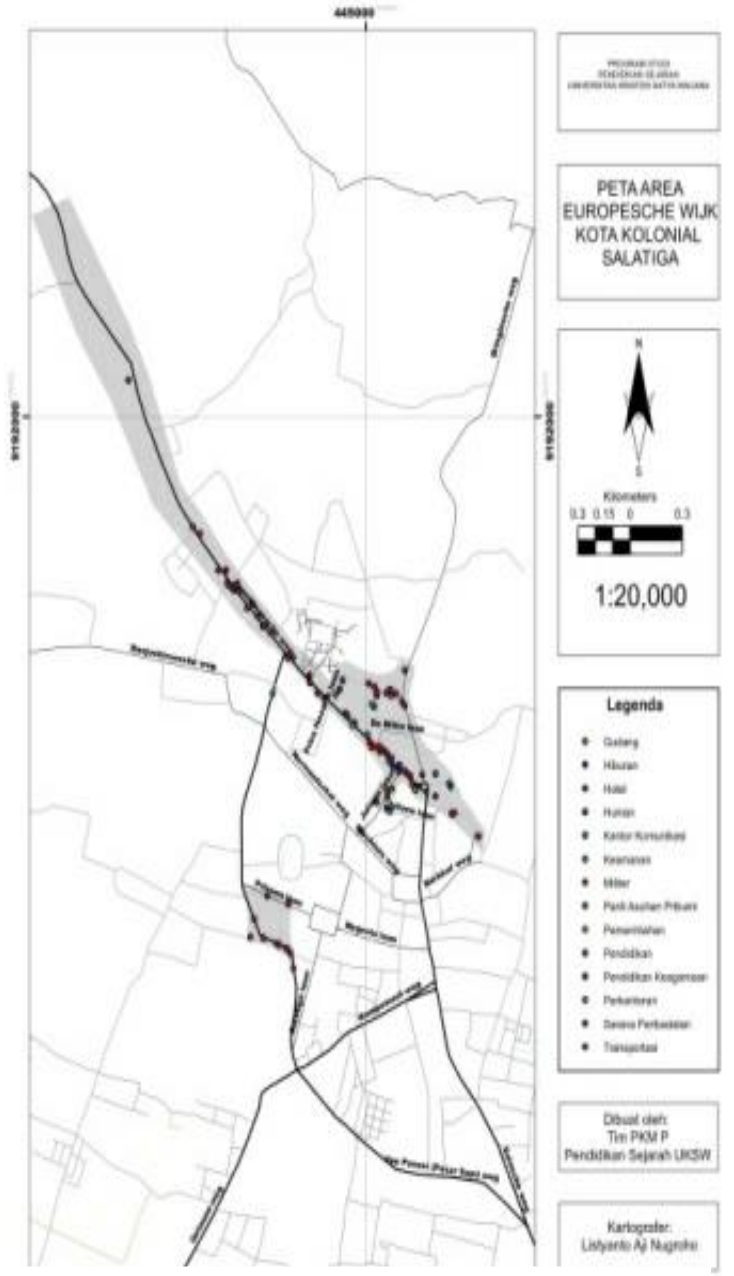

Gambar 2: Peta Kawasan Europesche Wijk Hal ini menguntungkan secara ekonomi, politik, maupun pertahanan. Pusat kota dapat dijangkau melalui jalan Tuntangscheweg, Bringinscheweg, Soloscheweg, dan satu jalan yang menjadi pusat rekreasi saat itu (kini bernama Jalan Pemuda). Di pusat kota terdapat kantor Asisten Residen yang menjadi pusat pemerintahan gemeente Salatiga. Untuk area pemukiman, teridentifikasi bahwa terdapat 3 zonasi wilayah pemukiman masyarakat. Wilayah-wilayah tersebut adalah zona Europesche Wijk ${ }^{2}$ (pemukiman orang Eropa) di sekitar Tuntangescheweg (sekarang adalah Jalan Diponegoro hingga jalur SalatigaTuntang), Chinesche Wijk ${ }^{3}$ (pemukiman warga Tionghoa) disekitar pasar, pemukiman elit pribumi di wilayah sekitar kepatihan (saat ini wilayah disekitar Lapangan Pancasila), dan pemukiman rakyat jelata yang berada di luar wilayah-wilayah elit. Selain itu ada juga wilayah yang difokuskan untuk kawasan pendidikan yaitu area Schoolweg yang saat ini menjadi Jalan Kartini dan kawasan militer di wilayah Kampementkini: Yonif 411.4

${ }^{1}$ Gambar 1: Peta Zonasi Kota Kolonial Salatiga (Sumber: Tim PKM Program Studi Pendidikan Sejarah, FKIP-UKSW, Tahun 2018/Artgis)

${ }^{2}$ Gambar 2: Peta Kawasan Europesche Wijk (Sumber: Tim PKM Program Studi Pendidikan Sejarah, FKIP-UKSW, Tahun 2018/Artgis)

${ }^{3}$ Gambar 3: Peta Kawasan Chinesche Wijk (Sumber: Tim PKM Program Studi Pendidikan Sejarah, FKIP-UKSW, Tahun 2018/Artgis)

${ }^{4}$ Gambar 4: Peta Kawasan Militer(Sumber: Tim PKM Program Studi Pendidikan Sejarah, FKIP-UKSW, Tahun 2018/Artgis) 


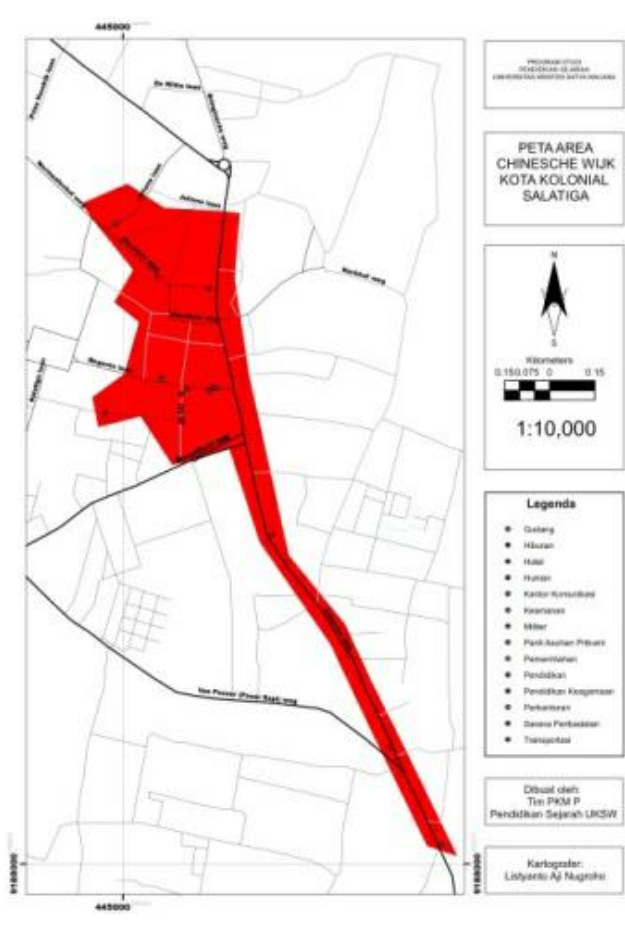

Gambar 3: Peta Kawasan Chinesche Wijk

Di zona Chinesche Wijk atau saat ini sekitar jalan Jendral Sudirman dan sekeliling pasar Salatiga merupakan wilayah dengan banyak sekali peninggalan kolonial bercorak Tionghoa. Wilayah ini memang sejak zaman Kolonial sudah menjadi wilayah yang banyak dihuni warga keturunan Tionghoa dengan sarana perekonomian, seperti: gudang, rumah lelang, rumah pemotongan hewan, gedung opera, dan bioskop Rex (Bioskop Reksa). Sedangkan untuk wilayah yang saat ini bernama Jalan Diponegoro, Jalan Yos Sudarso, Jalan Patimura, Jalan Moh. Yamin, pada masa Kolonial adalah zona Europesche Wijk dihuni oleh orang Eropa yang kaya raya. Di wilayah ini terdapat berbagai macam fasilitas umum seperti Gereja, kantor Asisten Residen dan Burgermeester, hotel, Gedung Societeit, asrama militer, benteng, perkantoran, dan banyak rumah tinggal. Selain di Jalan Diponegoro, terdapat juga kawasan Eropa lain di sekitar alun-alun kota (saat ini Lapangan Pancasila).

Untuk wilayah yang saat ini bernama Jalan Diponegoro, Jalan Yos Sudarso, Jalan Patimura, Jalan Moh. Yamin, pada masa Kolonial adalah zona Europesche Wijk dihuni oleh orang Eropa yang kaya raya. Di wilayah ini terdapat berbagai macam fasilitas umum seperti Gereja, kantor Asisten Residen dan Burgermeester, hotel, Gedung Societeit, asrama militer, benteng, perkantoran, dan banyak rumah tinggal. Selain di Jalan Diponegoro, terdapat juga kawasan Eropa lain di sekitar alun-alun kota (saat ini Lapangan Pancasila).

Sebagai sebuah kota Modern pada masa Kolonial, Kota Salatiga didukung oleh infrastruktur militer yang cukup memadai.

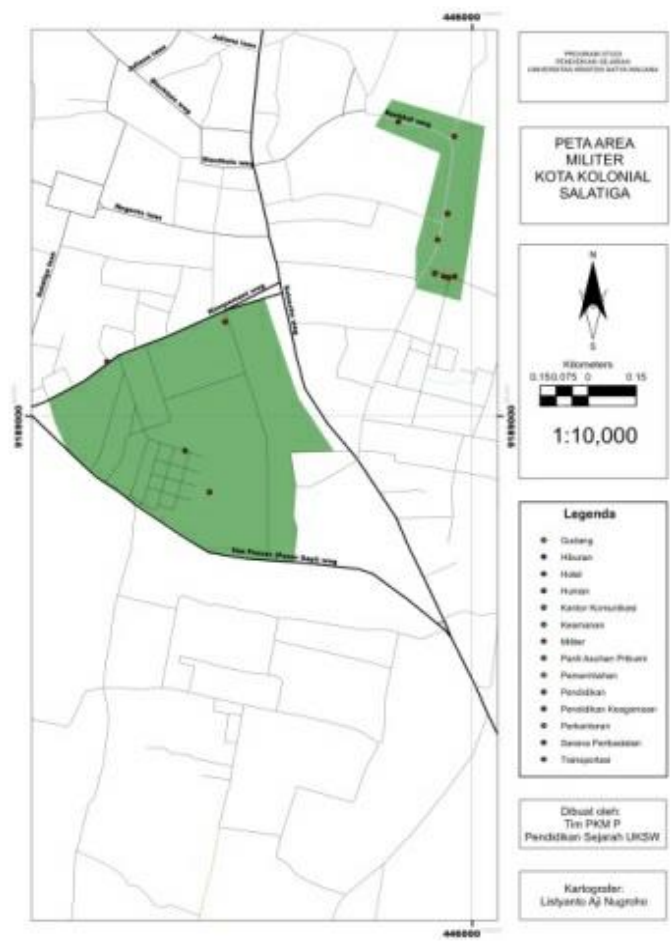

Gambar 4: Peta Kawasan Militer 
Terdapat sebuah barak pasukan kavaleri yang saat ini menjadi kawasan Yonif 411. Di kawasan ini terdapat lapangan berkuda dan sebuah landasan pacu. Selain barak kavaleri, di Jl. Dr. Muwardi juga terdapat pemukiman militer yang dilengkapi dengan fasilitas rumah sakit militer dan tanpa mengesampingkan elit pribumi, para elit (priyayi) juga memiliki wilayah huniannya sendiri di sekitar Kepatihan $^{5}$ (Lapangan Pancasila saat ini) hingga ke wilayah Sinoman (wilayah di sebelah barat Jetis saat ini). Di wilayah tersebut terdapat pusat pemerintahan tradisional yaitu Kepatihan. Dari segi pendidikan, infrastruktur pendidikan di Salatiga sangat memadahi. Sekitar Jl. Kartini terdapat sebuah kompleks yang hingga saat ini digunakan sebagai areal sekolahan (Schoolweg). ${ }^{6}$
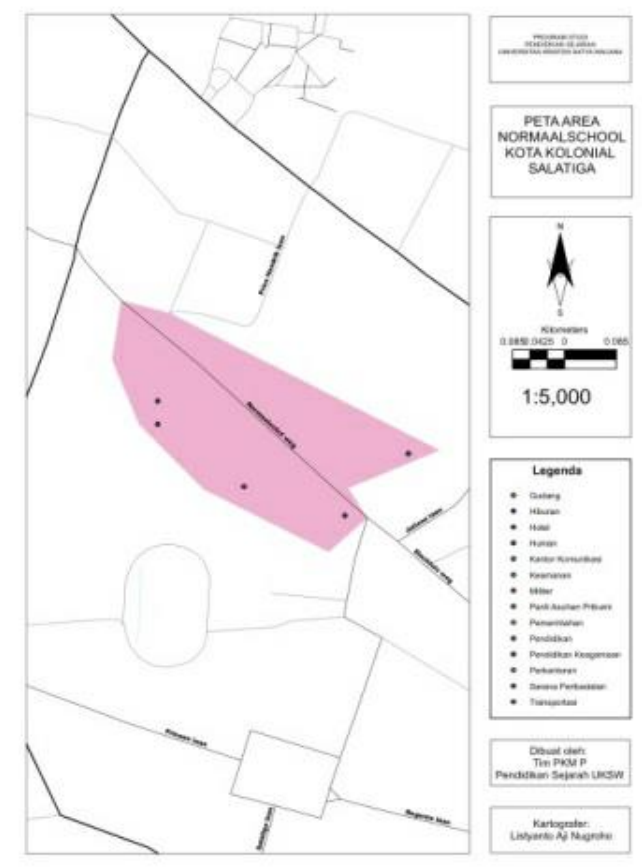

Peta perkembangan kota di atas merupakan sebagian dari kontribusi GIS dalam memberikan informasi yang salah satunya berkaitan dengan aspek kesejarahan dari keberlangsungan dari Kota Salatiga. Kota ini berkembang berkat dukungan sumber daya di sekitarnya. Posisinya yang diketinggian dan tanahnya yang subur, dan mudah diakses telah menjadi dukungan penting bagi perkembangan kota. Orang-orang Eropa pada periode itu dengan dengan suhu dingin kota, meskipun tidak sama dengan duhu dingin di negara asalnya Eropa.

\section{Gambar 6: Peta Kawasan schoolweg}

\footnotetext{
${ }^{5}$ Gambar 5: Peta Kawasan Elit Pribumi (Sumber: Tim PKM Program Studi Pendidikan Sejarah, FKIP-UKSW, Tahun 2018/Artgis)

${ }^{6}$ Gambar 6: Peta Kawasan schoolweg(Sumber: Tim PKM Program Studi Pendidikan Sejarah, FKIP-UKSW, Tahun 2018/Artgis)
} 


\section{KESIMPULAN}

Tatanan kota Salatiga masa Kolonial memiliki pola radial dan terpusat di tengah kota. Pola itu menguntungkan dari sisi pemerintahan, perekonomian, dan politik pertahanan. Dengan penggunaan GIS, diketahui bahwa Kota Salatiga pada masa Kolonial teridentifikasi memiliki 3 zonasi pola pemukiman, yaitu: Pertama, pola pemukiman yang khusus dihuni oleh orang-orang Eropa. Pola pemukiman itu disebut Europesche Wijk yang berlokasi di sekitar Tuntangescheweg, yaitu membentang dari Jalan Diponegoro sampai jalan Salatiga-Tuntang, juga di Jl. Diponegoro, Jl. Yos Sudarso, Jl. Patimura, dan Jl. Moh. Yamin. Kedua, Pola pemukiman yang masyarakatnya mayoritas orang-orang Tionghoa, dalam sejarah disebut Chinese Wijk. Lokasi Chinese Wijk adalah di Jl. Jenderal Sudirman dan di sekitar Pasar Kepatihan. Ketiga, Pola Pemukiman elite pribumi (priyayi). Kawasan ini terletak di sekitar Kepatihan atau di sekitar Lapangan Pancasila hingga ke Sinoman (sebelah barat Jetis).

Kontribusi GIS pada sejarah adalah pada pemetaan yang lebih akurat. Selain itu, fasilitas seperti pusat-pusat ekonomi, pendidikan, instalasi dan barak militer, dan jalur kereta api dapat dilakukan dengan tingkat akurasi yang ketat, sehingga GIS menghadirkan akurasi fakta dan membantu identifikasi lebih detail atas lapisan peristiwa sejarah yang terkait dengan ruang dan perubahan waktu. Gambaran itu dapat dilihat pada fasilitas pendidikan, fasilitas militer, rumah sakit, dan sebagainya. Area sekolah pada masa kolonial disebut Schoolweg yang berada di Jl. Kartini, di Kota Salatiga. Untuk kawasan militer adalah barak pasukan kaveleri yang dalam proses sejarahnya kini menjadi kompleks Yonif 411. Perumahan militer dan rumah sakit di dalamnya, terdapat di Jl. Dr. Muwardi, Kota Salatiga.

\section{DAFTAR PUSTAKA}

Balai Pelestarian Cagar Budaya. 2009. Kajian dan Identifikasi Bangunan Bersejarah di Kota Salatiga Tahun 2009. Salatiga: Bappeda Kota Salatiga.

Boechari. 2012. Melacak Sejarah Kuno Indonesia Lewat Prasasti; Kumpulan Tulisan Boechari. Jakarta: Kepustakaan Popular Gramedia.

Harini, T.M. Endah. 2010. "Pemanfaatan Benda-Benda Bersejarah Peninggalan Masa Kolonial Belanda Di Kota Salatiga Sebagai Sumber Belajar Di Sekolah Menengah Atas". Tesis. Surakarta: Universitas Sebelas Maret Surakarta.

Martasari, Ludhyana. 2016. “Pola Keruangan dan Fungsi Situs di Kawasan Situs Batujaya". Skripsi. Yogyakarta: FIB UGM

Prayoga, Rizal Yoga. 2016. “Pola Sebaran Temuan Arkeologis Masa Klasik di Lereng Timur Merapi Dan Faktor Yang Mempengaruhinya". Skripsi. Yogyakarta: FIB Universitas Gajah Mada. 
Wuryani, Emy. 2006. “Distrik Salatiga 1900 - 1942”. Tesis. Yogyakarta: Universitas Gajah Mada.

Yuwono, Jarwo Susetyo Edi. 2007. “Kontribusi Aplikasi Sistem Informasi Geografis Dalam Berbagai Skala Kajian Arkeologi Lansekap" Jurnal Berkala Arkeologi Th. XXVII Edisi No. 2/ November 2007. 